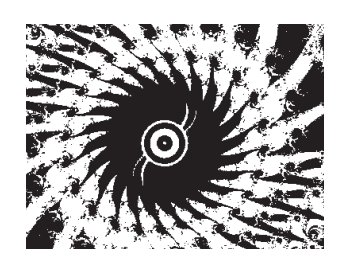

\title{
ULOGA \\ SVAKODNEVNIH \\ NEGATIVNIH DOGAĐAJA \\ U DEPRESIVNOSTI ADOLESCENATA
}

Ana KURTOVIĆ

Filozofski fakultet, Osiiek

Ivanka ŽIVČIĆ BEĆIREVIĆ

Filozofski fakultet, Rijeka

UDK: 616.895.4-053.6

Izvorni znanstveni rad

Primljeno: 9. 8. 2011.

Osnovni cili ovoga rada bio je provjeriti odnos svakodnevnih negativnih događaja s depresivnosti kod adolescenata. Nastojalo se u prvom redu provjeriti predviđaju li svakodnevni negativni događaii depresivne simptome kod adolescenata. Provjereno je i to moderiraju li negativne automatske misli, osjećaj opće samoefikasnosti, strategije suočavanja i percipirana podrška obitelii, vršnjaka i profesora odnos svakodnevnih negativnih događaja i depresivnosti ili posreduju u tom odnosu. Ispitivanje je provedeno na uzorku od 827 učenika srednje škole (535 učenica i 292 učenika). Rezultati analiza nisu utvrdili da negativne automatske misli, osjećaj opće samoefikasnosti, strategije suočavanja i percipirana podrška obitelii, vršnjaka i profesora moderiraju odnos svakodnevnih negativnih događaja i depresivnosti. S druge strane, rezultati upućuju na zaključak da je odnos svakodnevnih negativnih događaja i depresivnosti adolescenata posredovan negativnim automatskim mislima, suočavanjem usmierenim na emocije i podrškom obitelji, prijatelja i profesora.

Ključne riječi: svakodnevni negativni događaii, depresivnost, adolescenti

$\triangle$ Ana Kurtović, Studii psihologiie, Filozofski fakultet, Sveučilište J. J. Strossmayera u Osijeku, L. Jägera 9, 31000 Osijek, Hrvatska.

E-mail: akurtovi@ffos.hr 
Pojam stresora vrlo je važan u razvojnoj psihopatologiji. Većina dominantnih teorijskih modela dječje ili adolescentne psihopatologije prepoznaje važnost okolinskih stresora u etiologiji i održavanju internaliziranih i eksternaliziranih poremećaja. Stresori su okolinski doprinos riziku, koji u kombinaciji s osobnim čimbenicima osjetljivosti vode psihološkim problemima kod djece i adolescenata.

Mnoga istraživanja potvrđuju povezanost stresnih događaja i psihološke neugode. Naime, pokazuje se da stresni životni događaji predviđaju nastanak i pojačavanje depresivnih simptoma i kod odraslih $i$ kod djece $i$ adolescenata (Benson i Deeter, 2001.; Ge i sur., 1994.). Nekoliko istraživanja na našim prostorima također su potvrdila povezanost stresnih događaja, uključujući ratne događaje (Brajša Žganec, 2005.; Živčić, 1994.), zlostavljanje (Sesar i sur., 2008.), školski stres (Subotić i sur., 2008.) i svakodnevne neugodne događaje (Kurtović, 2007.) s depresivnosti i drugim problemima prilagodbe.

Životne okolnosti koje od osobe traže značajnu i trajnu prilagodbu osobito su relevantne jer zahtijevaju aktivaciju raznih resursa. Unatoč tome, istraživanja pokazuju da manji životni događaji ili dnevne tegobe pokazuju jaču povezanost $s$ depresivnim simptomima i kod odraslih i kod djece i adolescenata. Naime, pokazuje se da je akumulacija manjih životnih događaja bolji prediktor depresivnosti nego veliki životni događaji te da se ta povezanost pojačava s dobi (Adkins i sur., 2009.; Scott i sur., 2008.; Sund i sur., 2003.).

Iako su stresni događaji prisutni u svakom životnom razdoblju, adolescencija je osobito stresno razdoblje zbog velikih promjena na biološkom, kognitivnom i socijalnom planu. Pokazuje se da su mladi, koji proživljavaju više istodobnih životnih promjena, pod povećanim rizikom za razvoj depresivnosti te da je povezanost između životnih događaja i negativnog afekta jača $u$ ranoj adolescenciji nego u predadolescentnom razdoblju. Na temelju toga neki autori pretpostavljaju da je osjetljivost na efekte životnih događaja povećana u adolescenciji te da je to jedan od mogućih uzroka nagloga porasta depresivnosti (Ge i sur., 2001.). Jedan od čimbenika koji bi mogao pridonositi toj povećanoj osjetljivosti adolescenata na životne događaje jest njihova povećana kognitivna i emocionalna zrelost, ali i širenje opusa događaja koji djeluju na njih, uključujući romantične veze, sadašnje i prošle događaje, kompleksne socijalne situacije te stres koji se događa važnim osobama u životu (Alloy, 2001.; Pinea i sur., 2002.). Moguće je da kombinacija povećanoga broja događaja, povećane osjetljivosti na njih i smanjena kontrola nad njima dovodi do porasta depresivnosti $\mathrm{u}$ adolescenciji. 
DRUŠ. ISTRAŽ. ZAGREB GOD. 21 (2012), BR. $3(117)$

STR. 671-691

KURTOVIĆ, A., ŽIVČIĆ BEĆIREVIĆ, I.: ULOGA
Osim pitanja jesu li adolescenti osjetljiviji na efekte negativnih događaja i povećava li se učestalost događaja s ulaskom $\mathrm{u}$ adolescenciju, važno je pitanje i koji čimbenici mogu moderirati odnos negativnih događaja i depresivnosti te koji su potencijalni mehanizmi u podlozi.

Mnoga su se istraživanja bavila modelima koji mogu objasniti odnos stresa i prilagodbe, pa se pažnja uglavnom usmjerava na osobne i okolinske varijable (Adkins i sur., 2009.; Bhatia i Bhatia, 2007.; Thompson i sur., 2010.). Neki od čimbenika koji se konzistentno pokazuju značajnima u predviđanju depresivnosti jesu kognicije i suočavanje, kao osobni faktori, te socijalna podrška, kao faktor okoline.

Kognitivni modeli depresije pretpostavljaju da su pojedinci s negativnim kognitivnim tendencijama, u suočavanju sa stresom, pod povećanim rizikom za razvoj depresivnih simptoma. Iako se razni modeli usredotočuju na razne kognicije (slika o sebi, bespomoćnost, beznadnost, atribucijski stil, samoefikasnost), zajedničko im je stajalište da interakcija kognitivne osjetljivosti i stresa može rezultirati depresijom. Mnoga istraživanja potvrdila su pretpostavke da navedeni čimbenici, samostalno ili u kombinaciji sa stresom, pridonose depresivnoj simptomatologiji kod adolescenata (Bhatia i Bhatia, 2007.; Cole i sur., 2001.; Huang i sur., 2009.; Morris i sur., 2008.). Važno je napomenuti da istraživanja potvrđuju ulogu negativnih kognicija, kao i njihove interakcije sa stresom, u predviđanju trenutačnih simptoma depresije, ali i budućih epizoda (Abela i sur., 2009.; Kurtović, 2007.; Spence i sur., 2002.). Nadalje, neki autori smatraju da bi procjene samoefikasnosti mogle biti središnje za razumijevanje osjećaja neadekvatnosti kod depresivnih osoba (Tabassum i Rehman, 2005.). Naime, depresivni pojedinci često sebe ne vide kao dovoljno sposobne ili učinkovite da utječu na događaje i situacije u svojem životu onako kako bi došlo do poželjnih ishoda. Percepcija samoefikasnosti osobito je relevantna $u$ adolescenciji zbog povećanih zahtjeva na akademskom, socijalnom i kognitivnom planu te povećane potrebe za samostalnošću i ovladavanjem vještinama sličnim onima u odrasloj dobi. Studije pokazuju da depresivne osobe procjenjuju svoju efikasnost kao nedostatnu ili nedoraslu svojim osobnim standardima (Tabassum i Rehman, 2005.), osobito što se tiče akademske (Scott i sur., 2008.), tjelesne i socijalne samoefikasnosti (Oliver i Paull, 1995.; Wei i sur., 2005.).

Osim utjecaja kognicija, mnogi autori naglašavaju ulogu strategija suočavanja sa stresom u predviđanju depresivnosti, ali i u objašnjavanju odnosa stresa i prilagodbe. Istraživanja na odraslim osobama potvrđuju ulogu suočavanja u prilagodbi pojedinca, ali se također pokazuje da se sposobnosti i vještine suočavanja djece i adolescenata bitno razlikuju od o- 
DRUŠ. ISTRAŽ. ZAGREB GOD. 21 (2012) BR. $3(117)$

STR. 671-691

KURTOVIĆ, A., ŽIVČIĆ BEĆIREVIĆ, I. ULOGA... nih kod odraslih osoba, primarno zbog svoje ograničene mogućnosti aktivnog izbjegavanja stresora, ali i zbog osobne i financijske ovisnosti o roditeljima (Amirkhan i Auyeung, 2007.). Autori smatraju da nedovoljno razvijene vještine ili dominantna primjena neprimjerenih strategija, samostalno ili $u$ interakciji sa stresom, povećavaju vjerojatnost nepovoljnih ishoda. Istraživanja pokazuju da je aktivno, problemu usmjereno suočavanje povezano s dobrom prilagodbom kod adolescenata te s manjom zastupljenosti depresivnih simptoma. Pokazuje se i to da su pasivni, emocijama usmjereni načini suočavanja, povezani s depresivnim simptomima (Horwitz i sur., 2010.; Thompson i sur., 2010.; Sun i sur., 2010.). Neka istraživanja ističu i slabe vještine rješavanja problema (Spence i sur., 2002.) te ruminativni stil suočavanja s negativnim raspoloženjem (Abela i sur., 2009.), u kombinaciji sa stresom, kao osobito štetne za mentalno zdravlje adolescenata.

Konačno, većina studija pokazuje da je socijalna podrška, koja kod djece i adolescenata uključuje podršku roditelja, vršnjaka te učitelja/profesora, važan zaštitni čimbenik. Mnoga istraživanja potvrđuju da je socijalna podrška negativno povezana s depresivnosti (Flynn i sur., 2010.; Stice i sur., 2004.). Tako su Lev-Wiesel i suradnici (2006.) utvrdili da je socijalno odbijanje $u$ adolescenciji traumatski događaj i da je povezano $\mathrm{s}$ depresijom u odrasloj dobi. Međutim, što se tiče ublažavanja učinaka stresa, postoje istraživanja koja potvrđuju interakcijske efekte na depresivnost adolescenata, ali i ona koja nisu utvrdila takve interakcije (Flynn i sur., 2010.; Ritakallio i sur., 2010.). Čini se da je jedan od mogućih razloga različitih nalaza taj što su neki autori ispitivali efekte ukupne socijalne podrške, dok su drugi gledali posebno efekte podrške roditelja i vršnjaka.

Postoje mnogi čimbenici koji mogu oblikovati odnose životnih događaja i depresivnih simptoma, a većina istraživača do sada ih je tretirala kao faktore koji mogu ublažavati ili pojačavati učinke stresa. U skladu s takvim pristupom, valja očekivati da bi negativni događaji, $\mathrm{u}$ interakciji s negativnim automatskim mislima i pasivnim suočavanjem, mogli predviđati višu depresivnost. Isto tako može se pretpostaviti da adolescenti, koji doživljavaju puno negativnih događaja i imaju niski osjećaj samoefikasnosti, ne primjenjuju aktivne strategije suočavanja i nemaju dobru socijalnu podršku, pa također doživljavaju više depresivnih simptoma.

$\mathrm{S}$ druge strane, ako se uzme $\mathrm{u}$ obzir da je adolescencija razdoblje velikih promjena na kognitivnom, socijalnom i emocionalnom planu, opravdano je pretpostaviti da se kognicije, suočavanje i percepcija socijalne podrške mogu mijenjati pod utjecajem stresnih događaja te djelovati kao mehanizam utjecaja stresa na depresivnost. $\mathrm{S}$ obzirom na to da iste varijable 
DRUŠ. ISTRAŽ. ZAGREB GOD. 21 (2012), BR. 3 (117)

STR. 671-691

KURTOVIĆ, A., ŽIVČIĆ BEĆIRÉVIĆ, I.: ULOGA..

\section{METODA}

\section{Sudionici}

\section{Instrumenti}

mogu djelovati i kao moderatori i kao medijatori (Baron i Kenny, 1986.), u ovom smo istraživanju prihvatili oba pristupa. Prema tome, cilj ovog rada bio je dvojak. Prvo - nastojali smo provjeriti učinke interakcija negativnih događaja s negativnim automatskim mislima, samoefikasnosti, strategijama suočavanja te socijalnom podrškom na depresivnost. Drugo nastojali smo provjeriti posreduju li negativne automatske misli, samoefikasnost, strategije suočavanja sa stresom i socijalna podrška u odnosu negativnih događaja i depresivnosti kod adolescenata.

U istraživanju je sudjelovalo 827 učenika srednje škole, od čega 535 učenica i 292 učenika od 14 do 20 godina $(M=16,66 ; S D=1,19)$.

Skala percipiranih događaja za adolescente (APES; Adolescent Perceived Events Scale; Compas i sur., 1987.)

Skala percipiranih događaja za adolescente originalno sadrži 30 negativnih događaja koji se tipično događaju adolescentima, od velikih životnih događaja, kao što je rastava braka roditelja ili smrt člana obitelji, do svakodnevnih neugodnih iskustava, kao što je pritisak vršnjaka, nesuglasice s prijateljima i sl. Primijenjena je prilagođena Skala percipiranih događaja za adolescente (Kurtović, 2007.), koja sadrži 20 događaja, a sudionici trebaju odgovoriti koliko često su im se navedeni događaji događali u protekla 2 mjeseca na peterodijelnoj skali (1 - nikada, 2 - ponekad, 3 - umjereno često, 4 - često i 5 - stalno), pri čemu je mogući raspon rezultata od 20 do 100 . Skala je pokazala zadovoljavajuću pouzdanost uz koeficijent unutrašnje pouzdanosti tipa Cronbach-alpha $(\alpha=0,86)$.

Upitnik automatskih misli (Proroković i Zelić, 2002.) Upitnik automatskih misli - UPAM - jest adaptacija upitnika Automatic Thoughts Questionnaire (Hollon i Kendall, 1980.), koji je jedan od najčešćih instrumenata za procjenu negativnih automatskih misli povezanih s depresijom. Upitnik je uzet kao unidimenzionalna mjera čestine javljanja negativnih automatskih misli, s mogućim rasponom rezultata od 30 do 150, gdje viši rezultati upućuju na višu prisutnost negativnih automatskih misli. Koeficijent pouzdanosti tipa unutarnje konzistencije bio je 0,97.

Skala opće samoefikasnosti (Ivanov i Penezić, 1998.)

Skala opće samoefikasnosti mjeri opći i stabilan osjećaj vlastite efikasnosti u suočavanju s raznim stresnim situacijama. Skala se sastoji od 10 tvrdnji za koje ispitanik procjenjuje u 
DRUŠ. ISTRAŽ. ZAGREB GOD. 21 (2012) BR. $3(117)$

STR. 671-691

KURTOVIĆ, A. ŽIVČIĆ BEĆIRÉVIĆ, I.: ULOGA.. kojoj se mjeri odnose na njega na skali od 1 - uopće nije točno za mene do 5 - potpuno je točno za mene, s mogućim rasponom rezultata od 10 do 50. Skala je pokazala zadovoljavajuću pouzdanost uz koeficijent unutarnje konzistencije 0,86 .

Upitnik suočavanja sa stresnim situacijama

Endlera i Parkera - CISS (Sorić i Proroković, 2002.)

Upitnik suočavanja sa stresnim situacijama hrvatska je adaptacija upitnika Coping Inventory for Stressful Situations - CISS (Endler i Parker, 1990.), koji procjenjuje stilove suočavanja kao stabilne karakteristike ličnosti. Upitnik sadrži 48 čestica koje čine tri podskale (po 16 tvrdnji), a odnose se na tri dimenzije suočavanja: suočavanje usmjereno na emocije, suočavanje usmjereno na problem i izbjegavanje. Zadatak ispitanika jest da procijeni u kojoj mjeri primjenjuje određeni tip aktivnosti/ ponašanje kad se susretne s teškom, stresnom ili uznemirujućom situacijom na skali od pet stupnjeva (od 1 - uopće ne do 5 - potpuno da).

Stabilnost faktorske strukture provjerena je faktorskom analizom (metodom glavnih komponenti uz Varimax rotaciju), pa su ekstrahirana tri faktora, koja, uz nešto promijenjen broj čestica koje čine pojedine podskale, opisuju suočavanje usmjereno na problem (16 čestica, alfa $=0,86$ ), suočavanje usmjereno na emocije ( 18 čestica, alfa $=0,85)$ i izbjegavanje (13 česti$\mathrm{ca}$, alfa $=0,85)$.

Ljestvica procjene socijalne podrške (Hudek-Knežević, 1994.) Ljestvica procjene socijalne podrške jest adaptacija SS-A upitnika (Social Support Apraisal Scale; Vaux i sur., 1986.) na hrvatski jezik. Ljestvica mjeri tri aspekta socijalne podrške: podršku unutar obitelji, podršku prijatelja i podršku na poslu. Upitnik se sastoji od 24 čestice, a odgovara se na skali od 1 - Uopće nije točno za mene do 5 - Potpuno je točno za mene, pa je mogući raspon rezultata od 24 do 120 .

Za potrebe istraživanja, čestice koje mjere socijalnu podršku na poslu preformulirane su tako da opisuju socijalnu podršku za koju učenici percipiraju da je dobivaju u školi (od profesora).

Faktorskom analizom glavnih komponenata uz Varimax rotaciju potvrđena je trofaktorska struktura, koja opisuje podršku obitelji, prijatelja i profesora. Koeficijenti unutrašnje konzistencije za pojedine podskale bili su redom $0,87,0,90$ i 0,88.

Skala depresivnosti za djecu (Živčić, 1992.)

Skala depresivnosti za djecu jest hrvatska adaptacija CDI skale (Children's Depression Inventory; Kovacs, 1985.), koja se sastoji od 27 grupa od po tri čestice koje pokrivaju simptome 
DRUŠ. ISTRAŽ. ZAGREB GOD. 21 (2012), BR. 3 (117)

STR. 671-691

KURTOVIĆ, A. ŽIVČIĆ BEĆIREVIĆ, I.: ULOGA.

\section{Postupak}

\section{REZULTATI}

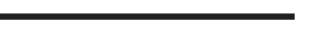

\begin{tabular}{lrrrrrr}
\hline & & & & & Mogući \\
& M & SD & Minimum & Maksimum & raspon & N \\
\hline Negativni događaji & 38,15 & 9,30 & 20,00 & 74,00 & $20-100$ & 769 \\
Automatske misli & 59,83 & 23,85 & 30,00 & 146,00 & $30-150$ & 753 \\
Samoefikasnost & 36,60 & 6,16 & 10,00 & 50,00 & $10-50$ & 785 \\
Suočavanje usmjereno na problem & 55,61 & 8,65 & 16,00 & 79,00 & $16-80$ & 752 \\
Suočavanje usmjereno na emocije & 51,80 & 10,69 & 18,00 & 85,00 & $18-90$ & 727 \\
Suočavanje izbjegavanjem & 43,74 & 9,28 & 13,00 & 65,00 & $13-65$ & 790 \\
Podrška obitelji & 35,46 & 6,07 & 9,00 & 77,00 & $8-40$ & 797 \\
Podrška prijatelja & 33,51 & 5,42 & 10,00 & 40,00 & $8-40$ & 785 \\
Podrška profesora & 25,12 & 6,12 & 8,00 & 40,00 & $8-40$ & 785 \\
Depresivnost & 12,81 & 7,30 & 0,00 & 50,00 & $0-54$ & 767 \\
\hline
\end{tabular}

(1) TABLICA 1 Deskriptivni podaci za negativne događaje, automatske misli, samoefikasnost, suočavanje usmjereno na problem, suočavanje usmjereno na emocije, suočavanje izbjegavanjem, podršku obitelii, prijatelja i profesora te depresivnost
U Tablici 1 prikazani su deskriptivni podaci ispitanih varijabli. Kao što se može vidjeti, učenici pokazuju niže razine depresivnosti, negativnih događaja i negativnih automatskih misli, što je očekivano s obzirom na to da se radi o uzorku zdravih sudionika. Podaci koji nedostaju tretirani su metodom listwise deletion, s obzirom na to da je veličina uzorka to dopuštala.

depresije kod djece, kao što su tuga, poremećaji sna, apetita te samoubilačke ideje. U svakoj grupi čestica varira intenzitet jednoga simptoma, a dijete bira onu od ponuđenih rečenica koja najbolje opisuje kako se ono osjeća u zadnja dva tjedna. Odgovori se boduju sa 0,1 ili 2 boda, što omogućuje raspon rezultata od 0 do 54 boda, pri čemu viši rezultat upućuje na višu depresivnost. Skala je primijenjena kao unidimenzionalna mjera depresivnosti te je pokazala zadovoljavajuću pouzdanost uz Cronbach-alfa od 0,87.

Ispitivanje se provodilo grupno $\mathrm{u}$ predmetnim učionicama, ovisno o rasporedu, tijekom dva sata iz istoga predmeta. Sudionicima je rečena opća uputa na početku ispitivanja, a svaki je mjerni instrument imao svoju specifičnu uputu prilagođenu svrsi istraživanja. Ispitivanje je u većini slučajeva trajalo jedan školski sat.

Prije provođenja analiza, a da bi se odgovorilo na postavljene probleme, izračunane su korelacije izmjerenih varijabli (Pearsonov r), koje su prikazane u Tablici 2.

Sve su izmjerene varijable pokazale značajne korelacije s depresivnosti u očekivanim smjerovima, a koeficijenti se kreću od $-0,15$ za suočavanje izbjegavanjem do 0,70 za negativne automatske misli.

Kako bi se provjerili efekti interakcija negativnih događaja s negativnim automatskim mislima, samoefikasnosti, su- 
DRUŠ. ISTRAŽ. ZAGREB GOD. 21 (2012) BR. $3(117)$

STR. 671-691

KURTOVIĆ, A. ŽIVČIĆ BEĆIRÉVIĆ, I.: ULOGA... očavanjem usmjerenim na problem, na emocije i suočavanjem izbjegavanjem te podrškom obitelji, prijatelja i profesora na depresivnost, proveden je niz hijerarhijskih regresijskih analiza. U prvi korak svake analize uvršteni su prediktori (negativni događaji i jedan od potencijalnih moderatora), a u drugom koraku njihova interakcija, kako bi se provjerilo predviđa li ta interakcija depresivnost nakon kontrole efekata prediktora $\mathrm{u}$ prvom koraku. Rezultati su prikazani u Tablici 3.

\begin{tabular}{|c|c|c|c|c|c|c|c|c|c|c|}
\hline & 1. & 2. & 3. & 4. & 5. & 6. & 7. & 8. & 9. & 10 \\
\hline 1. Negativni događaji & 1 & & & & & & & & & \\
\hline 2. Automatske misli & $0,47^{* *}$ & & & & & & & & & \\
\hline 3. Samoefikasnost & $-0,06$ & $-0,34^{* * *}$ & 1 & & & & & & & \\
\hline $\begin{array}{l}\text { 4. Suočavanje usmjereno } \\
\text { na problem } \\
\text { 5. Sucčavanie usmiereno }\end{array}$ & $-0,06$ & $-0,15^{* * *}$ & $0,61^{* * *}$ & +1 & & & & & & \\
\hline na emocije & $0,37^{* *}$ & $* * 0,54^{* * *}$ & $-0,19^{* * *}$ & $0,11^{* *}$ & 1 & & & & & \\
\hline 6. Suočavanje izbjegavanjem & 0,05 & $-0,07$ & $0,25^{* * *}$ & $* 0,39 * * *$ & * $0,17^{* * *}$ & +1 & & & & \\
\hline 7. Podrška obitelii & $-0,38^{* *}$ & $-0,33^{* *}$ & $0,26^{* *}$ & $0,22^{* *}$ & $-0,07$ & $0,16^{* *}$ & 1 & & & \\
\hline 8. Podrška prijatelja & $-0,13^{* *}$ & $-0,20 * *$ & $0,32 * *$ & $0,27^{* *}$ & $-0,05$ & $0,41^{* *}$ & $0,38^{* *}$ & 1 & & \\
\hline 9. Podrška profesora & $-0,33^{* *}$ & $-0,26^{* *}$ & $0,22^{* *}$ & $0,23^{* *}$ & $-0,09^{*}$ & $0,11^{* *}$ & $0,31^{* *}$ & $0,23^{* *}$ & * 1 & \\
\hline 10. Depresivnost & $0,48^{* *}$ & $* * 0,70 * * *$ & $-0,38^{* * *}$ & $-0,26^{* * *}$ & * $0,44^{* * *}$ & ${ }^{*}-0,15^{* * *}$ & $-0,39 * *$ & $-0,26^{* *}$ & * $-0,40^{* *}$ & $* 1$ \\
\hline
\end{tabular}

${ }^{*} \mathrm{p}<0,05,{ }^{* *} \mathrm{p}<0,01,{ }^{* * *} \mathrm{p}<0,001$

(1) TABLICA 2

Interkorelacije ispitanih varijabli
$\mathrm{Ni}$ jedna interakcija nije pokazala značajne efekte na depresivnost, osim granično značajnog efekta interakcije negativnih događaja i podrške obitelji, što ne potvrđuje pretpostavku da navedeni čimbenici moderiraju efekte negativnih događaja na depresivnost.

Kako bi se provjerilo posreduju li negativne automatske misli, samoefikasnost, strategije suočavanja i socijalna podrška u odnosu negativnih događaja i depresivnosti, proveden je niz hijerarhijskih regresijskih analiza prema preporukama Barona i Kennyja (1986.). Kako bi se moglo zaključiti da je određena varijabla medijator u odnosu prediktor i kriterij varijable, moraju biti zadovoljena tri uvjeta. Prvo, prediktor mora predviđati medijator, drugo, medijator mora predviđati kriterij nakon kontrole prediktora, i treće, uključivanjem medijatora u zadnji korak hijerarhijske regresijske analize doprinos prediktora objašnjenju varijance kriterija treba pasti na razinu koja nije značajna. Što se tiče trećeg uvjeta, ako doprinos prediktora prestane biti značajan, radi se o potpunoj medijaciji. S druge strane, ako je efekt prediktora smanjen, ali i dalje značajan, radi se o djelomičnoj medijaciji.

Rezultati regresijskih analiza kojima je provjeravan prvi uvjet, odnosno predviđaju li negativni događaji automatske misli, samoefikasnost, strategije suočavanja i podršku obitelji, prijatelja i profesora, prikazani su u Tablici 4. 
(1) TABLICA 3

Rezultati hijerarhijskih

regresijskih analiza za

kriterii depresivnost

$\begin{array}{lllll} & \text { F- } & \text { Ukupni } & \\ \mathrm{R} & \mathrm{R}^{2} & \text {-promjena } & \mathrm{F} & \text { Beta }\end{array}$

Automatske misli

1. korak Negativni događaji Automatske misli

2. korak Negativni događaji x Automatske misli

$\begin{array}{lllll}0,73 & 0,542 & 394,849^{* * *} & 394,849^{* * *} & 0,179^{* * *} \\ & & & & 0,633^{* * *} \\ 0,73 & 0,542 & 0,031 & 262,858^{* * *} & 0,005\end{array}$

Samoefikasnost

1. korak Negativni događaji Samoefikasnost

$\begin{array}{ccccc}0,58 & 0,34 & 179,9^{* * *} & 179,99^{* * *} & \begin{array}{l}0,46^{* * *} \\ -0,33^{* * *}\end{array} \\ 0,58 & 0,34 & 0,68 & 120,17^{* * *} & -0,02\end{array}$

2. korak Negativni događaji $x$ Samoefikasnost

Suočavanje usmjereno na problem

1. korak Negativni događaji Suočavanje usmjereno na problem

2. korak Negativni događaji $x$ Suočavanje usmjereno na problem

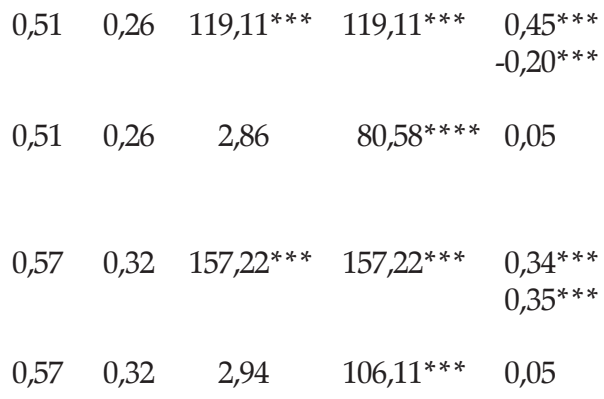

$0,57 \quad 0,32 \quad 157,22^{* * *}$

$0,57 \quad 0,32 \quad 2,94 \quad 106,11^{* * *} \quad 0,05$

Suočavanje usmjereno na emocije

1. korak Negativni događaji Suočavanje usmjereno na emocije

2. korak Negativni događaji $x$ Suočavanje usmjereno na emocije

Suočavanje izbjegavanjem

1. korak Negativni događaji Suočavanje izbjegavanjem

2. korak Negativni događaji $x$ Suočavanje izbjegavanjem

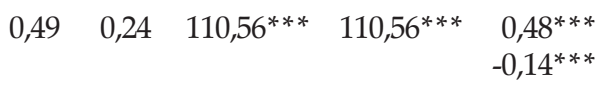

Podrška obitelji

1. korak Negativni događaji Podrška obitelji

2. korak Negativni događaji x Podrška obitelji Podrška prijatelja

1. korak Negativni događaji Podrška prijatelja

$0,54 \quad 0,28 \quad 138,12^{* * *} \quad 138,12^{* * *} \quad 0,41^{* * *}$

$0,54 \quad 0,28 \quad 3,74 \quad 93,69^{* * *} \quad 0,07$ $(\mathrm{p}=0,054)$

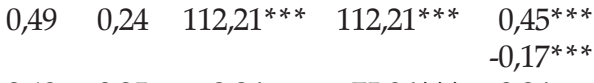

2. korak Negativni događaji x Podrška prijatelja $\quad 0,49 \quad 0,25 \quad 2,86 \quad 75,96^{* * *} \quad 0,06$ Podrška profesora

1. korak Negativni događaji $0,53 \quad 0,28 \quad 135,63^{* * *} \quad 135,63^{* * *} \quad 0,39^{* * *}$ Podrška profesora $-0,25^{* * *}$

$\begin{array}{llllll}2 . & \text { korak Negativni događaji x Podrška profesora } \quad 0,53 & 0,28 & 1,28 & 90,88^{* * *} & 0,04\end{array}$

${ }^{* * *} \mathrm{p}<0,001$ 


\begin{tabular}{lrrrrr}
\hline & Beta & $\mathrm{t}$ & $\mathrm{p}$ & $\mathrm{R}$ & $\mathrm{R}^{2}$ \\
\hline Automatske misli & 0,47 & 14,23 & 0,001 & 0,47 & 0,22 \\
Samoefikasnost & $-0,05$ & $-1,48$ & 0,138 & 0,06 & 0,00 \\
Suočavanje usmjereno na problem & $-0,06$ & $-1,62$ & 0,104 & 0,06 & 0,00 \\
Suočavanje usmjereno na emocije & 0,36 & 10,32 & 0,001 & 0,37 & 0,13 \\
Suočavanje izbjegavanjem & 0,05 & 1,59 & 0,111 & 0,05 & 0,00 \\
Podrška obitelji & $-0,37$ & $-11,13$ & 0,001 & 0,37 & 0,14 \\
Podrška prijatelja & $-0,13$ & $-3,45$ & 0,001 & 0,13 & 0,02 \\
Podrška profesora & $-0,33$ & $-9,55$ & 0,001 & 0,33 & 0,11 \\
\hline
\end{tabular}

(1) TABLICA 4

Rezultati regresijskih analiza s negativnim događajima kao prediktorom te automatskim mislima, samoefikasnošću strategijama suočavanja i podrškom obitelii, prijatelia i profesora kao kriterijima
(1) TABLICA 5

Rezultati proviere uloge automatskih misli, suočavanja usmierenog no emocije te podrške obitelji, prijatelia i profesora kao medijatora odnosa negativnih događaja i depresivnosti
Utvrđeno je da negativni događaji predviđaju automatske misli, suočavanje usmjereno na emocije i socijalnu podršku, pa je daljnja analiza rađena samo s automatskim mislima, suočavanjem usmjerenim na emocije te podrškom obitelji, prijatelja i profesora u drugom koraku.

Kako bi se provjerili drugi i treći uvjet, posegnuli smo za hijerarhijskom regresijskom analizom, gdje su u prvom koraku uvršteni negativni događaji, a u drugom automatske misli, suočavanje usmjereno na emocije i socijalna podrška. Odlučeno je da se $u$ drugom koraku uvrste navedene varijable zajedno, umjesto da se analize rade posebno za svaki potencijalni medijator, kako bi se moglo provjeriti je li odnos negativnih događaja i depresivnosti potpuno posredovan tim varijablama. Naime, depresivnost je multideterminiran konstrukt, zbog čega je vjerojatno da bismo dobili djelomične medijacije za pojedine medijatore. Također, zbog interkorelacija među medijatorima, veća je vjerojatnost spuriozne korelacije. Na taj se način u drugom koraku hijerarhijske regresijske analize može vidjeti koje su varijable samostalno značajni prediktori depresivnosti nakon kontrole negativnih događaja te iz toga zaključiti o njihovu medijacijskom efektu. Tablica 5 prikazuje rezultate hijerarhijske regresijske analize.

\begin{tabular}{|c|c|c|c|c|c|c|}
\hline Prediktori & $\mathrm{R}$ & $\mathrm{R}^{2}$ & $\begin{array}{l}\text { F- } \\
\text {-promjena }\end{array}$ & $\begin{array}{l}\text { Ukupni } \\
\text { F }\end{array}$ & Beta & $\begin{array}{l}\text { Parc. } \\
\mathrm{r}\end{array}$ \\
\hline \multicolumn{7}{|l|}{ 1. korak } \\
\hline Negativni događaji & 0,48 & 0,24 & $169,93^{* * *}$ & $169,93^{* * *}$ & $0,48^{* * *}$ & $0,48^{* * *}$ \\
\hline \multicolumn{7}{|l|}{ 2. korak } \\
\hline Negativni događaji & & & & & 0,050 & 0,050 \\
\hline Automatske misli & & & & & $0,500 * * *$ & $0,370^{* * *}$ \\
\hline Suočavanje usmjereno na emocije & 0,78 & 0,6 & $107,58^{* * *}$ & $145,17^{* * *}$ & $-0,170^{* * *}$ & $0,140^{* * *}$ \\
\hline Podrška obitelji & & & & & $-0,162^{* * *}$ & $-0,139 * * *$ \\
\hline Podrška prijatelja & & & & & $-0,060^{*}$ & $-0,057^{*}$ \\
\hline Podrška profesora & & & & & $-0,164^{* * *}$ & $-0,149^{* * *}$ \\
\hline
\end{tabular}

${ }^{*} \mathrm{p}<0,05,{ }^{* * *} \mathrm{p}<0,001$

Kao što se može vidjeti iz Tablice 5, u drugom koraku hijerarhijske regresijske analize automatske misli, suočavanje 
DRUŠ. ISTRAŽ. ZAGREB GOD. 21 (2012), BR. $3(117)$

STR. 671-691 ŽIVČIĆ BEĆIREVIĆ, I.: ULOGA
KURTOVIĆ, A.,

usmjereno na emocije te podrška obitelji, prijatelja i profesora pokazuju značajne samostalne doprinose objašnjenju varijance depresivnosti. Također, doprinos negativnih događaja objašnjenju varijance depresivnosti nakon uključivanja automatskih misli, suočavanja usmjerenog na emocije i socijalne podrške $u$ analizu više nije značajan (parc. kor $=0,05 ; p>0,05$ ). Prema tome, rezultati sugeriraju da je veza negativnih događaja i depresivnosti posredovana automatskim mislima, suočavanjem usmjerenim na emocije te podrškom obitelji, prijatelja i profesora.

\section{RASPRAVA}

Cilj ovog rada bio je provjeriti odnose svakodnevnih neganosti, strategija suočavanja i socijalne podrške s depresivnosti na uzorku srednjoškolaca.

Svakodnevni negativni događaji predviđali su depresivnost kod srednjoškolaca, što je u skladu s modelima stresa i mnogim istraživanjima na uzorcima djece, adolescenata i odraslih osoba. Naime, mnoga istraživanja pokazuju da akumulacija stresnih događaja, osobito onih nad kojima osoba nema kontrolu, uvelike pridonose razvoju potkliničkih i kliničkih razina depresije. Međutim, treba napomenuti da je u ovom istraživanju ispitivana učestalost svakodnevnih tegoba koje su tipične za razdoblje adolescencije. Budući da se nije ispitivala percipirana kontrola nad takvim događajima, teško je zaključivati predviđa li sama količina i učestalost negativnih događaja depresivnost kod adolescenata ili se taj odnos može objasniti karakteristikama ispitanih događaja.

S obzirom na dosadašnje spoznaje pretpostavili smo da će negativne automatske misli te pasivni oblici suočavanja sa stresom pojačavati, a da će samoefikasnost, aktivni oblici suočavanja i socijalna podrška ublažavati efekte negativnih događaja na depresivnost.

Iako se pokazalo da navedeni čimbenici predviđaju depresivne simptome kod adolescenata, nisu utvrđeni značajni interakcijski efekti. Prema tome, naši rezultati nisu u skladu s pretpostavkama o moderaciji učinka negativnih događaja na depresivnost.

Autori navode da se moderacijski odnosi najčešće testiraju onda kada su veze prediktora i kriterija relativno slabe ili nekonzistentne, kako bi se otkrili uvjeti pod kojima prediktor utječe na kriterij. Također naglašavaju da se moderacijski učinci najbolje mogu vidjeti kada moderator nije značajno povezan s prediktorom ni s kriterijem (Baron i Kenny, 1986.; Frazier i sur., 2004.). S obzirom na to da su svi potencijalni moderatori značajno povezani s depresivnosti, a automatske mitivnih događaja, negativnih automatskih misli, samoefikas- 
DRUŠ. ISTRAŽ. ZAGREB GOD. 21 (2012) BR. $3(117)$

STR. 671-691

KURTOVIĆ, A., ŽIVČIĆ BEĆIREVIĆ, I. ULOGA... sli, suočavanje usmjereno na emocije te socijalna podrška i s negativnim događajima, moguće je da je to razlog zašto nisu utvrđeni interakcijski efekti. Naime, čini se da automatske misli, samoefikasnost, strategije suočavanja i socijalna podrška izravno utječu na depresivnost, neovisno o razinama negativnih događaja. Konceptualno, moderator varijable jesu stabilne karakteristike, koje pojačavaju ili ublažavaju učinke stresa, odnosno upućuju na to jesu li efekti generalni ili ograničeni na određene uvjete. Moguće je da u ovom razvojnom periodu kognicije, suočavanje i socijalna podrška još nisu dovoljno stabilni da bi mogli moderirati učinke stresa, iako sami pridonose razvoju depresivnosti.

$S$ druge strane, naši rezultati sugeriraju da je odnos negativnih događaja i depresivnosti potpuno posredovan negativnim automatskim mislima, emocijama usmjerenim suočavanjem i slabom podrškom roditelja, prijatelja i profesora.

Za razliku od moderatora, medijator varijable promjenjive su pod utjecajem nezavisne varijable, pa onda utječu na promjene u zavisnoj varijabli. Na taj način one objašnjavaju mehanizme utjecaja jedne varijable na drugu. Iz razvojne perspektive može se očekivati da je kognitivni stil djece i adolescenata te njihov stil suočavanja pod utjecajem situacijskih i kontekstualnih faktora, odnosno da životne okolnosti i događaji utječu na promjene $u$ kognicijama vezanim uz njih i strategijama koje oni rabe u suočavanju sa stresom te na taj način djeluju na depresivne simptome.

Mnogi autori smatraju da doživljavanje razočaranja, gubitaka, neuspjeha i drugih neugodnih događaja tijekom razvoja može utjecati na pojedinčev pogled na život, osobito ako su ti događaji ozbiljni i ako se ponavljaju. Rose i Abramson (1992.) predložili su model koji naglašava ulogu negativnih događaja u nastanku kognitivne osjetljivosti. Oni smatraju da kada se dogode takvi negativni događaji, pojedinci nastoje razumjeti uzroke, značenje i posljedice, a ponavljanjem misli koje su specifične za te događaje formira se općenitiji kognitivni stil. Osobito neugodni događaji koji imaju mnogo ozbiljnih posljedica mogu dovesti do univerzalnog osjećaja bespomoćnosti i beznadnosti, a osobe koje smatraju da su same odgovorne za te događaje vjerojatnije će razviti osjećaj osobne bespomoćnosti i niskoga samopoštovanja (Garber i Flynn, 2001.). Parker i suradnici (2000.) pokazali su da čak i rana negativna iskustva utječu na razvoj negativnih kognicija kasnije u životu. Prema tome, moguće je da neugodni događaji, osobito ako su kronični, djeluju na depresivnost tako što pogoduju stvaranju negativnih kognicija o sebi, svijetu, budućnosti i drugim ljudima. Međutim, u ovom istraživanju pokazalo se da i svakodnevni negativi događaji, odnosno dnevne tegobe, predviđaju negativne automatske misli. S ob- 
DRUŠ. ISTRAŽ. ZAGREB GOD. 21 (2012), BR. $3(117)$

STR. 671-691

KURTOVIĆ, A., ŽIVČIĆ BEĆIREVIIĆ, I.: ULOGA... zirom na to da su veći životni događaji uglavnom manje učestali, moguće je da oni pružaju temelj za negativne misli, koje se onda sa svakodnevnim iskustvima iznova aktiviraju i potvrđuju te na taj način dobivaju kroničan karakter i potiču stvaranje stabilnijega kognitivnog stila.

Osim negativnih automatskih misli, pokazalo se da i suočavanje usmjereno na emocije posreduje u odnosu negativnih događaja i depresivnosti. Rezultati sugeriraju da veća količina negativnih događaja predviđa primjenu neadaptivnih strategija suočavanja te na taj način pogoduje razvoju depresivnih simptoma. Istraživanja koja su tretirala suočavanje kao moderatora odnosa stresa s mentalnim zdravljem uglavnom su zanemarivala činjenicu da je suočavanje dinamičan proces te nisu promatrala kovarijacije stresa, suočavanja i ishoda (Jose i Huntsinger, 2005.). Wadsworth i suradnici (2005.) smatraju da djeca stječu sposobnosti za primjenu strategija suočavanja kako sazrijevaju, pa da je zato njihov stil suočavanja podložan promjenama pod utjecajem iskustva. S druge strane, čini se da su stilovi suočavanja odraslih osoba više dispozicijski, što sugerira da pojedinci, što su stariji, stječu sve stabilnije obrasce suočavanja. Njihovi rezultati potvrdili su pretpostavke da kod adolescenata odgovori na stres posreduju između stresa i psihopatoloških simptoma, dok kod odraslih moderiraju efekte stresa. Međutim, oni su ispitivali efekte kroničnoga stresa izazvanog lošim socioekonomskim statusom, koji sam može imati taj učinak da povećava osjetljivost osobe jer smanjuje kapacitete za suočavanje sa svakodnevnim stresorima i smanjuje raspoloživu socijalnu podršku. Njihovi rezultati ne odgovaraju na pitanje može li veća količina svakodnevnih tegoba povećati osjetljivost osobe na depresivnost time što djeluje na strategije suočavanja. No postoje istraživanja koja pokazuju da suočavanje može biti pod utjecajem kumulativnog efekta negativnih događaja koji se događaju istodobno ili u brzom slijedu, $\mathrm{i}$ to tako da potiču neadaptivne strategije suočavanja, kao što su ventiliranje emocija i izbjegavanje (Ebata i Moos, 1994.). Moguće je da više stresnih događaja i situacija pogoduje razvoju tendencije za primjenom manje adaptivnih strategija suočavanja, kao što je emocijama usmjereno suočavanje, jer smanjuje kapacitete za primjenu aktivnih strategija suočavanja. Naime, ako dijete ili adolescent doživljava više stresnih događaja, vjerojatno će doživljavati i više neugodnih emocija kao reakcije na takve događaje i situacije. U takvim stanjima smanjuju se kapaciteti za aktivno planiranje postupaka, razmišljanje i traženje mogućih rješenja problema, racionalnu procjenu situacije, prisjećanje prijašnjih uspješno riješenih situacija i sl., pa je vjerojatnije da će osoba pribjeći drugim načinima suočavanja, na primjer onima kojima će smanjiti neugodne emocije koje doživljava. 
DRUŠ. ISTRAŽ. ZAGREB GOD. 21 (2012) BR. 3 (117),

STR. 671-691

KURTOVIĆ, A., ŽIVČIĆ BEĆIREVIĆ, I. ULOGA...
Prema tome, što češće dijete doživljava negativno uzbuđenje, češće će primijeniti strategije kojima bi smanjilo to uzbuđenje, a rjeđe strategije kojima bi aktivno djelovao na problem ili događaj, osobito ako nema dovoljno kontrole nad tim događajima i situacijama, što bi moglo djelomično objasniti vezu veće količine negativnih događaja i viših razina depresivnosti. S obzirom na rezultate istraživanja koja pokazuju da adolescenti doživljavaju više životnih događaja i promjena nego mlađa djeca (Pinea i sur., 2002.), moguće je da to djeluje na primjenu neadaptivnih strategija te da su zbog toga osobito osjetljivi na depresivne simptome. Jose i Huntsinger (2005.) ustanovili su da je suočavanje izbjegavanjem posredovalo između stresa (veliki i manji životni događaji) i negativne prilagodbe kod adolescenata.

Konačno, rezultati su pokazali da je veza negativnih događaja i depresivnosti posredovana nižom percipiranom socijalnom podrškom, obitelji, prijatelja i profesora. Lin i suradnici (1979.) pretpostavili su da socijalna podrška može imati dvije funkcije. Prva je funkcija antecendenta, odnosno čimbenika koji može smanjiti vjerojatnost nepovoljnih ishoda, a druga je funkcija otpornika, koji može ublažiti efekte stresnih iskustava. S obzirom na to da se $\mathrm{u}$ adolescenciji događaju mnoge promjene na socijalnom planu, najviše $\mathrm{u}$ odnosu s roditeljima i vršnjacima, moguće je da zbog toga adolescenti nemaju dovoljno stabilnu percepciju podrške koja bi mogla ublažavati učinke negativnih događaja. S druge strane, naši rezultati sugeriraju da su jedan od čimbenika koji pridonose toj nestabilnosti percepcije socijalne podrške upravo negativni događaji. Naime, Skala percipiranih događaja za adolescente (Compas i sur., 1987.) mjeri frekvenciju doživljavanja svakodnevnih neugodnih iskustava, kao što su problemi s prijateljima, problemi u školi, sukobi s roditeljima i sl., dakle većina je događaja interpersonalne prirode. $\mathrm{S}$ obzirom na to da rezultati mnogih istraživanja pokazuju da najsnažnije efekte na mentalno zdravlje i emocionalne reakcije pojedinaca imaju interpersonalni stresni događaji (Ebata i Moos, 1994.; Scott i sur., 2008.), izgleda da je jedan od mehanizama tog utjecaja taj da smanjuje percepciju podrške koju osoba dobiva od okoline. Važno je spomenuti i to da su efekti podrške roditelja i profesora bili veći od efekta podrške prijatelja, što je u skladu s nalazima koji pokazuju da su za dobrobit adolescenata važniji odnosi s roditeljima nego oni s vršnjacima te da se uloga roditelja u adolescenciji ne smanjuje (Deković i Janssens, 1992.). Neki autori sugeriraju da su efekti podrške roditelja i prijatelja kvalitativno različiti (Liu, 2006.; De Minzi, 2006.). Naime, oni smatraju da podrška prijatelja zahtijeva socijalne kompetencije te da je jače povezana sa socijalnim vještinama nego podrška roditelja. Oni sugeriraju da vršnjaci služe kao sekundarni 
DRUŠ. ISTRAŽ. ZAGREB GOD. 21 (2012), BR. 3 (117)

STR. 671-691

KURTOVIĆ, A., ŽIVČIĆ BEĆIREVIĆ, I. ULOGA izvor podrške, odnosno da se adolescenti njima okreću za podršku onda kada primarni izvori, roditelji, zakažu.

Iako nema puno istraživanja koja su provjeravala efekte podrške profesora, postoje nalazi koji sugeriraju da je za emocionalnu dobrobit adolescenata važna i podrška drugih odraslih osoba u životu (Cheng i sur., 2010.). S obzirom na to da je škola mjesto gdje se adolescenti suočavaju s mnogim izazovima i mogu doživjeti uspjeh i neuspjeh, razumljivo je da podrška profesora može imati zaštitne efekte na depresivnost. Slične rezultate dobili su Rosenthal i suradnici (2009.), koji su utvrdili da je odsutnost socijalne podrške, osobito emocionalne, rizičan čimbenik depresivnosti kod adolescenata. Oni osobito naglašavaju važnost odraslih osoba od povjerenja, ne samo roditelja, u zaštiti mentalnoga zdravlja adolescenata.

Zaključno, naši rezultati sugeriraju da $\mathrm{u}$ adolescentnom razdoblju treba razmatrati i neposredne i posredne odnose negativnih događaja i depresivnosti. Iako postoje mnogi nalazi koji upućuju na to da depresivnost može biti reakcija na negativne događaje, osobito one velike, čini se da je odnos svakodnevnih tegoba s depresivnosti posredovan negativnim kognicijama, pasivnim suočavanjem i slabom socijalnom podrškom. Naime, naši nalazi upućuju na nekoliko mehanizama kojima negativni životni događaji mogu voditi prema depresivnim simptomima te da te čimbenike ne treba tretirati kao stabilne osobine, nego prije kao karakteristike ili vještine koje su pod utjecajem mnogih faktora, između ostalog i svakodnevnih tegoba.

Ovakve i slične spoznaje o prediktivnoj moći negativnih događaja, automatskih misli, suočavanja te socijalne podrške mogu pomoći u procjeni rizika za razvoj depresivnih, ali i drugih simptoma, te mogu biti korisni u planiranju intervencijskih i prevencijskih postupaka. Osim toga, korisna su i znanja o potencijalnim mehanizmima kojima negativni događaji djeluju na depresivnost, jer pružaju informacije o čimbenicima na koje bi trebalo usmjeriti pažnju kod osoba koje su pod povišenim stresom. Međutim, važno je napomenuti da su negativni događaji samo jedan od faktora koji mogu predviđati negativne kognicije, suočavanje i percepciju socijalne podrške te da bi buduća istraživanja mogla pridonijeti znanjima o drugim čimbenicima koji predviđaju te varijable.

Treba napomenuti jedno važno pitanje, koje u ovom radu nije provjereno, a to je uloga spola u odnosima ispitanih varijabli i depresivnosti kod adolescenata. Naime, istraživanja pokazuju da između 12. i 15. godine djevojke počinju pokazivati znatno veću stopu depresivnosti nego mladići, dok u predadolescentnom razdoblju dječaci često pokazuju više razine depresivnosti od djevojčica (Stemmler i Petersen, 2005.). 
DRUŠ. ISTRAŽ. ZAGREB GOD. 21 (2012) BR. $3(117)$

STR. 671-691

KURTOVIĆ, A. ŽIVČIĆ BEĆIREVIĆ, I. ULOGA...

\section{LITERATURA}

Mnogi autori nastojali su na razne načine objasniti taj preokret, između ostalog i razlikama u količini neugodnih događaja i doživljaju stresa (Ge i sur., 1994.), kognitivnom stilu (Kuehner, 2003.), suočavanju (Nolen-Hoeksema, 2001.) i interpersonalnoj orijentaciji (Crawford i sur., 2001.). Međutim, postoje i nalazi koji sugeriraju da su djevojke podložnije utjecaju nekih rizičnih čimbenika, čak i ako oni nisu više izraženi. Na primjer, pokazalo se da se povezanost negativnih događaja i depresivnosti djevojaka povećava $u$ adolescenciji, dok se kod mladića smanjuje (Angold i sur., 1998.). S obzirom na navedeno, moguće je da, i na našem uzorku, postoje spolne razlike u nekim ispitanim varijablama, ali i da bi se odnosi negativnih događaja i drugih čimbenika s depresivnosti mogli razlikovati kod djevojaka i mladića.

Na kraju treba spomenuti i neka ograničenja ovog istraživanja. Prije svega, korelacijski i transverzalni nacrt onemogućuje zaključivanje o uzročno-posljedičnim odnosima te o tome prethode li vremenski negativni događaji promjenama u razinama depresivnih simptoma. Osim toga, primijenjene su mjere samoprocjene, što ograničuje mogućnost zaključivanja o kliničkim razinama depresije. Samoprocjene negativnih događaja također mogu biti pod utjecajem pogreški pamćenja. Nadalje, sudionici su bili učenici srednje škole koji su doživljavali niže razine depresivnosti, što također umanjuje mogućnost zaključivanja o odnosima negativnih događaja, automatskih misli, suočavanja i socijalne podrške s kliničkim razinama depresivnosti.

Abela, J. R. Z., Parkinson, C., Stolow, D. i Starrs, C. (2009.), A Test of the Integration of the Hopelessness and Response Styles Theories of Depression in Middle Adolescence. Journal of Clinical Child and Adolescent Psychology, 38 (3): 354-364. doi:10.1080/15374410902851630

Adkins, D. E., Wang, V., Dupre, M. E., van den Oord, E. J. C. G., Elder Jr., G. H. (2009.), Structure and Stress: Trajectories of Depressive Symptoms across Adolescence and Young Adulthood. Social Forces, 88 (1): 31-80. doi:10.1353/sof.0.0238

Alloy, L. B. (2001.), The Developmental Origins of Cognitive Vulnerability to Depression: Negative Interpersonal Context Leads to Personal Vulnerability. Cognitive Therapy and Research, 25 (4): 349-351. doi:10.1023/A:1005527218169

Amirkhan, A. i Auyeung, B. (2007.), Coping with Stress across the Lifespan: Absolute vs. Relative Changes in Strategy. Journal of Applied Developmental Psychology, 28 (4): 298-317. doi:10.1016/j.appdev. 2007.04.002

Angold, A., Costello, E. J. i Worthman, C. M. (1998.), Puberty and Depression: The Roles of Age, Pubertal Status and Pubertal Timing. Psychological Medicine, 28 (1): 51-61. doi:10.1017/S003329179700593X 
DRUŠ. ISTRAŽ. ZAGREB GOD. 21 (2012), BR. $3(117)$

STR. $671-691$

KURTOVIĆ, A., ŽIVČIĆ BEĆIREVIĆ, I.: ULOGA.
Baron, R. M. i Kenny, D. A. (1986.), The Moderator-Mediator Variable Distinction in Social Psychology Research: Conceptual, Strategic, and Statistical Considerations. Journal of Personality and Social Psychology, 51 (6): 1173-1182. doi:10.1037//0022-3514.51.6.1173

Benson, L. T. i Deeter, T. E. (2001.), Moderators of the Relation between Stress and Depression during Adolescence. School Counselor, 39 (3): 23-34.

Bhatia, S. K. i Bhatia, S. C. (2007.), Childhood and Adolescent Depression. American Academy of Family Psychiatrics, 75 (1): 22-35.

Brajša Žganec, A. (2005.), The Long-Term Effects of War Experiences on Children's Depression in the Republic of Croatia. Child Abuse and Neglect, 29 (1): 31-43. doi:10.1016/j.chiabu.2004.07.007

Cheng, E. S., Greenberger, E., Chuansheng, C., Heckhausen, J. i Farruggia, S. (2010.), Nonparental Adults as Social Resources in the Transition to Adulthood. Journal of Research on Adolescence, 20 (4): 1065-1082. doi:10.1111/j.1532-7795.2010.00662.x

Cole, D. A., Jacquez, F. M. i Maschman, T. L. (2001.), Social Origins of Depressive Cognitions: A Longitudinal Study of Self-Perceived Competence in Children. Cognitive Therapy and Research, 48 (4): 377-395.

Compas, B. E., Davis, G. E., Forsythe, C. J. i Wagner, B. M. (1987.), Assessment of Major and Daily Stressful Events during Adolescence: The Adolescent Perceived Events Scale. Journal of Consulting and Clinical Psychology, 55 (4): 534-541. doi:10.1037//0022-006X.55.4.534

Crawford, T. N., Cohen, P., Midlarsky, E. i Brook, J. S. (2001.), Internalizing Symptoms in Adolescence: Gender Differences in Vulnerability to Parental Distress and Discord. Journal of Research on Adolescence, 11 (1): 95-118. doi:10.1111/1532-7795.00005

Deković, M. i Janssens, M. A. (1992.), Parents' Child Rearing Style and Child's Sociometric Status. Developmental Psychology, 28 (5): 925-932.

De Minzi, R. M. C. (2006.), Loneliness and Depression in Middle to Late Childhood: The Relationship to Attachment and Parental Styles. Journal of Genetic Psychology, 167 (2): 189-210. doi:10.3200/GNTP.167. 2.189-210

Ebata, A. T. i Moos, R. H. (1994.), Personal, Situational, and Contextual Correlates of Coping in Adolescence. Journal of Research on Adolescence, 4 (1): 99-125. doi:10.1207/s15327795jra0401_6

Endler, N. S. i Parker, J. D. A. (1990.), The Multidimensional Assessment of Coping: A Critical Evaluation. Journal of Personality and Social Psychology, 58 (5): 844-855. doi:10.1037//0022-3514.58.5.844

Flynn, M., Kecmanovic, J. i Alloy, L. B. (2010.), An Examination of Integrated Cognitive-Interpersonal Vulnerability to Depression: The Role of Rumination, Perceived Social Support, and Interpersonal Stress Generation. Cognitive Therapy and Research, 34 (5): 456-466. doi:10. 1007/s10608-010-9300-8

Frazier, P. A., Tix, A. P. i Barron, K. E. (2004.), Testing Moderator and Mediator Effects in Counseling Psychology Research. Journal of Counseling Psychology, 51 (1): 115-134. doi:10.1037/0022-0167.51.1.115

Garber, J. i Flynn, C. (2001.), Predictors of Depressive Cognitions in Young Adolescents. Cognitive Therapy and Research, 25 (4): 353-376. doi:10.1023/A:1005530402239 
DRUŠ. ISTRAŽ. ZAGREB GOD. 21 (2012) BR. 3 (117),

STR. $671-691$

KURTOVIĆ, A., ŽIVČIĆ BEĆIRÉVIĆ, I.: ULOGA..
Ge, X., Conger, R. D. i Elder, G. H. (2001.), The Relation between Puberty and Psychological Distress in Adolescent Boys. Journal of Research on Adolescence, 11 (1): 49-70. doi:10.1111/1532-7795.00003

Ge, X., Lorenz, F. O., Conger, R. D., Elder, G. H. i Simons, R. L. (1994.), Trajectories of Stressful Life Events and Depressive Symptoms during Adolescence. Developmental Psychology, 30 (4): 467-483. doi:10.1037// 0012-1649.30.4.467

Hollon, S. D. i Kendall, P. C. (1980.), Cognitive Self-Statements in Depression: Development of an Automatic Thoughts Questionnaire. Cognitive Therapy and Research, 4 (4): 383-395. doi:10.1007/BF01178214

Horwitz, A. H., Hill, R. M. i King, C. A. (2010.), Specific Coping Behaviors in Relation to Adolescent Depression and Suicidal Ideation. Journal of Adolescence, 86 (5): 1-9.

Huang, J. P., Xia, W., Sun, C. H., Zhang, H. Y. i Wu, L. J. (2009.), Psychological Distress and Its Correlates in Chinese Adolescents. Australian and New Zealand Journal of Psychiatry, 43: 674-681. doi:10.1080/ 00048670902970817

Hudek-Knežević, J. (1994.), Obilježja ličnosti, biološki spol i percepcija socijalne podrške kao korelati suočavanja sa stresnim situacijama. Godišnjak Zavoda za psihologiju, 3: 47-56.

Ivanov, L. i Penezić, Z. (1998.), Skala opće samoefikasnosti (General Self-Efficacy Scale). U: K. Lacković Grgin, A. Proroković, V. Ćubela i Z. Penezić (ur.), Zbirka psihologijskih skala i upitnika (str. 156), Zadar, Sveučilište u Zadru.

Jose, P. E. i Huntsinger, C. S. (2005.), Moderation and Mediation Effects of Coping by Chinese Adolescents and European American Adolescents. The Journal of Genetic Psychology, 166 (1): 16-43. doi:10. 3200/GNTP.166.1.16-44

Kovacs, M. (1985.), The Children's Depression, Inventory (CDI). Psychopharmacological Bulletin, 21 (4): 995-998.

Kuehner, C. (2003.), Gender Differences in Unipolar Depression: An Update of Epidemiological Findings and Possible Explanations. Acta Psychiatrica Scandinavia, 108 (3): 183-174. doi:10.1034/j.1600-0447.2003. 00204.x

Kurtović, A. (2007.), Odnos atribucijskih dimenzija, negativnih životnih događaja i depresivnosti: Provjera modela beznadnosti. Psihologijske teme, 16 (1): 159-182.

Lev-Wiesel, R., Nuttman-Shwartz, O. i Sternberg, R. (2006.), Peer Rejection During Adolescence: Psychological Long-Term Effects. Journal of Loss and Trauma, 11: 131-142. doi:10.1080/15325020500409200

Lin, N., Simeone, R. S., Ensen, W. M. i Kuo, W. (1979.), Social Support, Stressful Life Events and Illness: A Model and an Empirical Test. Journal of Health and Social Behavior, 20 (2): 108-119. doi:10.2307/2136433

Liu, Y. (2006.), Paternal/Maternal Attachment, Peer Support, Social Expectations of Peer Interaction, and Depressive Symptoms. Adolescence, 41 (164): 705-722.

Morris, M. C., Ciecla, J. A. i Garber, J. (2008.), A Prospective Study of the Cognitive-Stress Model of Depressive Symptoms in Adolescents. Journal of Abnormal Psychology, 117 (4): 719-734. doi:10.1037/a0013741 
DRUŠ. ISTRAŽ. ZAGREB GOD. 21 (2012), BR. $3(117)$

STR. $671-691$

KURTOVIĆ, A., ŽIVČIĆ BEĆIRÉVIĆ, I.: ULOGA...
Nolen-Hoeksema, S. (2001.), Gender Differences in Depression. Current Directions in Psychological Science, 10 (5): 173-177. doi:10.1111/ 1467-8721.00142

Oliver, J. M. i Paull, J. C. (1995.), Self-Esteem and Self-Efficacy: Perceived Parenting and Family Climate, and Depression in University Students. Journal of Clinical Psychology, 51 (4): 466-489. doi:10.1002/ 1097-4679(199507)51:4<467::AID-JCLP2270510402>3.0.CO;2-0

Parker, G., Gladstone, G., Mitchell, P., Wilhelm, K. i Roy, K. (2000.), Do Early Adverse Experiences Establish a Cognitive Vulnerability to Depression on Exposure to Mirroring Life Events in Adulthood? Journal of Affective Disorders, 57 (1-3): 209-215. doi:10.1016/S0165-0327(99)00091-9

Pinea, D. S., Cohenb, P., Johnsonb, J. G. i Brookc, J. S. (2002.), Adolescent Life Events as Predictors of Adult Depression. Journal of Affective Disorders, 68: 49-57. doi:10.1016/S0165-0327(00)00331-1

Proroković, A. i Zelić, S. (2002.), Upitnik automatskih misli - UPAM (Automatic Thoughts Questionnaire). U: A. Proroković, K. Lacković Grgin, V. Ćubela Adorić i Z. Penezić (ur.), Zbirka psihologijskih skala $i$ upitnika (str. 79-84), Zadar, Sveučilište u Zadru.

Ritakallio, M., Luukkaala, T., Marttunen, M., Pelkonen, M. i KaltialaHeino, R. (2010.), Comorbidity between Depression and Antisocial Behaviour in Middle Adolescence: The Role of Perceived Social Support. Nord J Psychiatry, 64 (3): 164-171. doi:10.3109/08039480903264911

Rose, D. T. i Abramson, L. Y. (1998.), Developmental Predictors of Depressive Cognitive Style: Research and Theory. U: D. Chicchetti i S. Toth (ur.), Developmental Perspectives on Depression (str. 323-349), Rochester NY, University of Rochester Press.

Rosenthal, B. S., Wilson, W. C. i Futch, V. A. (2009.), Trauma, Protection, and Distress in Late Adolescence: A Multi Determinant Approach. Adolescence, 44 (176): 693-703.

Scott, W. D., Dearing, E., Reynolds, W. R., Lindsay, J. E., Baird, G. L. i Hamill, S. (2008.), Cognitive Self-Regulation and Depression: Examining Academic Self-Efficacy and Goal Characteristics in Youth of a Northern Plains Tribe. Journal of Research on Adolescence, 18 (2): 379-394. doi:10.1111/j.1532-7795.2008.00564.x

Sesar, K., Živčić-Bećirević, I. i Sesar, D. (2008.), Multi-Type Maltreatment in Childhood and Psychological Adjustment in Adolescence: Questionnaire Study among Adolescents in Western Herzegovina Canton. Croatian Medical Journal, 49: 243-56. doi:10.3325/cmj.2008.2.243

Sorić, I. i Proroković, A. (2002.), Upitnik suočavanja sa stresnim situacijama Endlera i Parkera (CISS). U: A. Proroković, K. Lacković Grgin, V. Ćubela Adorić i Z. Penezić (ur.), Zbirka psihologijskih skala i upitnika (str. 147-151), Zadar, Sveučilište u Zadru.

Spence, S. H., Sheffield, J. i Donovan, C. (2002.), Problem-Solving Orientation and Attributional Style: Moderators of the Impact of Negative Life Events on the Development of Depressive Symptoms in Adolescence. Journal of Clinical Child Psychology, 31 (2): 219-229. doi:10.1207/S15374424JCCP3102 07

Stemmler, M. i Petersen, A. C. (2005.), Gender Differential Influences of Early Adolescent Risk Factors for the Development of Depressive Affect. Journal of Youth and Adolescence, 34 (3): 175-183. doi:10.1007/ s10964-005-4299-y 
DRUŠ. ISTRAŽ. ZAGREB GOD. 21 (2012) BR. 3 (117),

STR. 671-691

KURTOVIĆ, A. ŽIVČIĆ BEĆIRÉVIĆ, I.: ULOGA..
Stice, E., Ragan, J. i Randall, P. (2004.), Prospective Relations Between Social Support and Depression: Differential Direction of Effects for Parent and Peer Support? Journal of Abnormal Psychology, 113 (1): 155-159. doi:10.1037/0021-843X.113.1.155

Subotić, S., Brajša-Žganec, A. i Merkaš, M. (2008.), Školski stres i neka obilježja ličnosti kao prediktori suicidalnosti adolescenata. Psihologijske teme, 17 (1): 111-131.

Sun, Y., Tao, F., Hao, J. i Wan, Y. (2010.), The Mediating Effects of Stress and Coping on Depression among Adolescents in China. Journal of Child and Adolescent Psychiatric Nursing, 23 (3): 173-180. doi:10. 1111/j.1744-6171.2010.00238.x

Sund, A. M., Larsson, B. i Wichstrom, L. (2003.), Psychosocial Correlates of Depressive Symptoms among 12-14-Year-Old Norwegian Adolescents. Journal of Child Psychology and Psychiatry, 44 (4): 588-597. doi:10.1111/1469-7610.00147

Tabassum, U. i Rehman, G. (2005.), The Relationship Between Self-Efficacy and Depression in Physically Handicapped Children. Journal of Pakistan Psychiatric Society, 2 (1): 37-42.

Thompson, R. J., Mata, J., Jaeggi, S. M., Buschkuehl, M., Gotlib, I. H. i Jonides, J. (2010.), Maladaptive Coping, Adaptive Coping, and Depressive Symptoms: Variations across Age and Depressive State. Behaviour Research and Therapy, 48 (6): 459-466. doi:10.1016/j.brat.2010. 01.007

Vaux, A., Phillips, J., Holly, L., Thomson, B., Williams, D. i Stewart, D. (1986.), The Social Support Appraisal (SS-A) Scale: Studies of Reliability and Validity. American Journal of Community Psychology, 14 (2): 195-219. doi:10.1007/BF00911821

Wadsworth, M. E., Raviv, T., Compas, B. E. i Connor Smith, J. K. (2005.), Parent and Adolescent Responses to Poverty-Related Stress: Test of Mediated and Moderated Coping Models. Journal of Child and Family Studies, 14 (2): 283-298. doi:10.1007/s10826-005-5056-2

Wei, M., Russell, D. W. i Zakalik, R. A. (2005.), Adult Attachment, Social Self-Efficacy, Self-Disclosure, Loneliness, and Subsequent Depression for Freshman College Students: A Longitudinal Study. Journal of Counseling Psychology, 52 (4): 602-614. doi:10.1037/00220167. 52.4 .602

Živčić, I. (1994.), Depresionost u dječjoj dobi kao reakcija na stresne životne događaje izazvane ratnom situacijom. Doktorska disertacija, Odsjek za psihologiju, Filozofski fakultet u Zagrebu.

Živčić, I. (1992.), Prikaz skale depresivnosti za djecu. Godišnjak Zavoda za psihologiju, 1: 173-179. 
DRUŠ. ISTRAŽ. ZAGREB GOD. 21 (2012), BR. 3 (117)

STR. $671-691$

KURTOVIĆ, A., ŽIVČIĆ BEĆIREVIĆ, I. ULOGA

\section{The Role of Negative Everyday Events in Adolescent Depression}

\author{
Ana KURTOVIĆ \\ Faculty of Humanities and Social Sciences, Osijek \\ Ivanka ŽIVČIĆ BEĆIREVIĆ \\ Faculty of Humanities and Social Sciences, Rijeka
}

The main purpose of this study was to examine the relationship of everyday negative events and depression in adolescents. Primarily, we tried to determine whether everyday negative events predicted depression symptoms in adolescents. Also, we examined whether negative automatic thoughts, general self-efficacy, coping strategies and support from family, friends and teachers moderated the relationship between everyday negative events and depression, or if they mediated the said relationship. The research was conducted on a sample of 827 high school students (535 girls and 292 boys). The results did not confirm that negative automatic thoughts, general self-efficacy, coping strategies and support from family, friends and teachers moderate the relationship of negative everyday events and depression. On the other hand, results suggest that negative automatic thoughts, emotion focused coping and support from family, friends and teachers mediate the relationship of negative everyday events and depression in adolescents.

Keywords: negative everyday events, depression, adolescents 